\title{
Spatial variability in sexual and asexual reproduction of the fissiparous seastar Coscinasterias muricata: the role of food and fluctuating temperature
}

\author{
Mattias Sköld ${ }^{*}$, Michael F. Barker, Philip V. Mladenov \\ Department of Marine Science, University of Otago, PO Box 56, Dunedin, New Zealand
}

\begin{abstract}
Populations of the fissiparous seastar Coscinasterias muricata were surveyed around New Zealand to determine the frequency of asexual reproduction. Seastars from an intertidal population from the Maori Bay (North Island) and 2 shallow subtidal-intertidal sites in Otago Harbour on the east coast of the South Island had split, were asymmetrical, had multiple madreporites and skewed sex ratios when gonads were present. In contrast, none of the populations from 13 subtidal populations from the fjords on the west coast or a subtidal population from Stewart Island had characters indicating that they had recently split. Examination of genetic diversity using allozymes agreed with morphological interpretations; the populations from the Maori Bay and the east coast (Otago Harbour) had significantly lower genotypic diversity than expected, while the fjord populations had genotypic diversity that conformed to expectations under sexual outcrossing. We investigated the effects of food supply and fluctuating temperature on growth, energy storage, gonad development and fission of $C$. muricata from a fissiparous population in Otago Harbour. Growth, gonad development and the pyloric caeca index increased with increased food supply. No effects were found due to the fluctuating temperature regime. Fission occurred in all treatments except when the seastars were starving, as indicated by decrease in size. Gonad development and energy storage under intermediate food supply were similar to measurements of individuals in the field, and suggest food limitation for the population studied. Since fissiparity decreases with increasing size in C. muricata and growth rates and gonad development increase with supply of food, we propose that the occurrence of apparently fewer fissiparous individuals in habitats where food is abundant is correlated to food supply. Rapid growth would allow individuals to more quickly reach the size threshold at which fission begins to be suppressed. Conversely, where food supply or feeding time is limiting growth, the pattern would be a relative increase in abundance of small fissiparous individuals. However, populations from the fjords and Stewart Island do not seem to undergo fission at all. A possible explanation could be that the asexual mode of reproduction of this species is not triggered in the sheltered subtidal fjord environment. Another possibility could be that natural selection acts against asexual reproduction by fission in the fjord environment, or that the ability to split was lost due to founder effects and random genetic drift when the fjords were successively colonised following the rise in sea level after the last ice-age.
\end{abstract}

KEY WORDS: Echinodermata $\cdot$ Asteroidea $\cdot$ Asexual/clonal reproduction $\cdot$ Fissiparity $\cdot$ Genotypic diversity $\cdot$ Allozymes $\cdot$ New Zealand $\cdot$ Fjord

\section{INTRODUCTION}

${ }^{*}$ Present address: National Board of Fisheries, Department of Coastal and Freshwater Resources, Box 423, 40126

Göteborg, Sweden. E-mail: mattias.skold@fiskeriverket.se
Asexual reproduction is common in marine invertebrates (Giese \& Pearse 1974, Hughes 1989), but with few exceptions (see Judson \& Normark 1996) all asex- 
ual species also seem able to reproduce sexually. Spatial and temporal scales of asexual and sexual recruitment generally differ for species with mixed modes of reproduction, and the general pattern is that sexual propagules disperse, whereas the asexually produced individuals remain near their origin (Williams 1975). Interpretations of the characteristics of populations with a mixed mode of reproduction should thus be based on which mode of recruitment is most significant (Johnson \& Threlfall 1987).

Biotic and abiotic factors that regulate the expression and relative proportion of asexual and sexual reproduction in heterogonic species are poorly understood. Physiological stress, small body size and poor nutrition have been associated with asexual reproduction in sea anemones and echinoderms (e.g. Chia 1976, Bucklin 1987, Lawrence \& Herrera 2000). Anthony \& Svane (1995) showed experimentally that habitat instability significantly increased asexual reproduction through fragmentation (pedal laceration) in the sea anemone Metridium senile. The most common form of asexual reproduction in echinoderms is division of the body, usually termed fissiparity. This form of proliferation is not very common in the phylum, and is only known to occur in 21 species of seastars (of ca. 1600), 45 brittlestars (of ca. 2000) and 8 seacucumbers (of ca. 900) so far (Mladenov \& Burke 1994). Although uncommon in the phylum, asexual species can be very successful, range widely, and occur in high densities in certain habitats. For most species, the asexual mode is related to small body size, while sexual maturity usually is attained after an individual reaches a certain size. Between-habitat variation in levels of asexual and sexual reproduction has also been documented in seastars (Emson \& Wilkie 1980). Observations that subtidal populations generally have a larger body size, a lower incidence of fission and larger gonads than intertidal populations has led to the generality that the asexual phenotype is associated with harsher, less stable resource-poor environments, whereas the sexual phenotype is associated with more favourable, stable and resource-rich environments. In some seastars it has also been observed that fission can be triggered by stress during unintended laboratory holding conditions such as elevated temperature, interruption of seawater circulation, and lack of aeration (Mladenov et al. 1983). These findings and generalisations have raised the question of environmental factors modulating and triggering fission, but few studies have actually tested these observations. However, M. F. Barker, R. Scheibling \& P. V. Mladenov (unpubl. data) have shown that in the laboratory fission occurred in well-fed Allostichaster insignis but was absent in starved individuals. (See also reviews by Emson \& Wilkie 1980, Mladenov \& Burke 1994, Mladenov 1996.)

Coscinasterias muricata (=C. calamaria) is a widely distributed species in the Indo-Pacific region and is one of the most common seastars in New Zealand waters. It occupies both intertidal and subtidal habitats but is usually restricted to sheltered sites such as harbours and wave-protected shores (Barker 1977). It is a critical predator, especially in the subtidal communi-

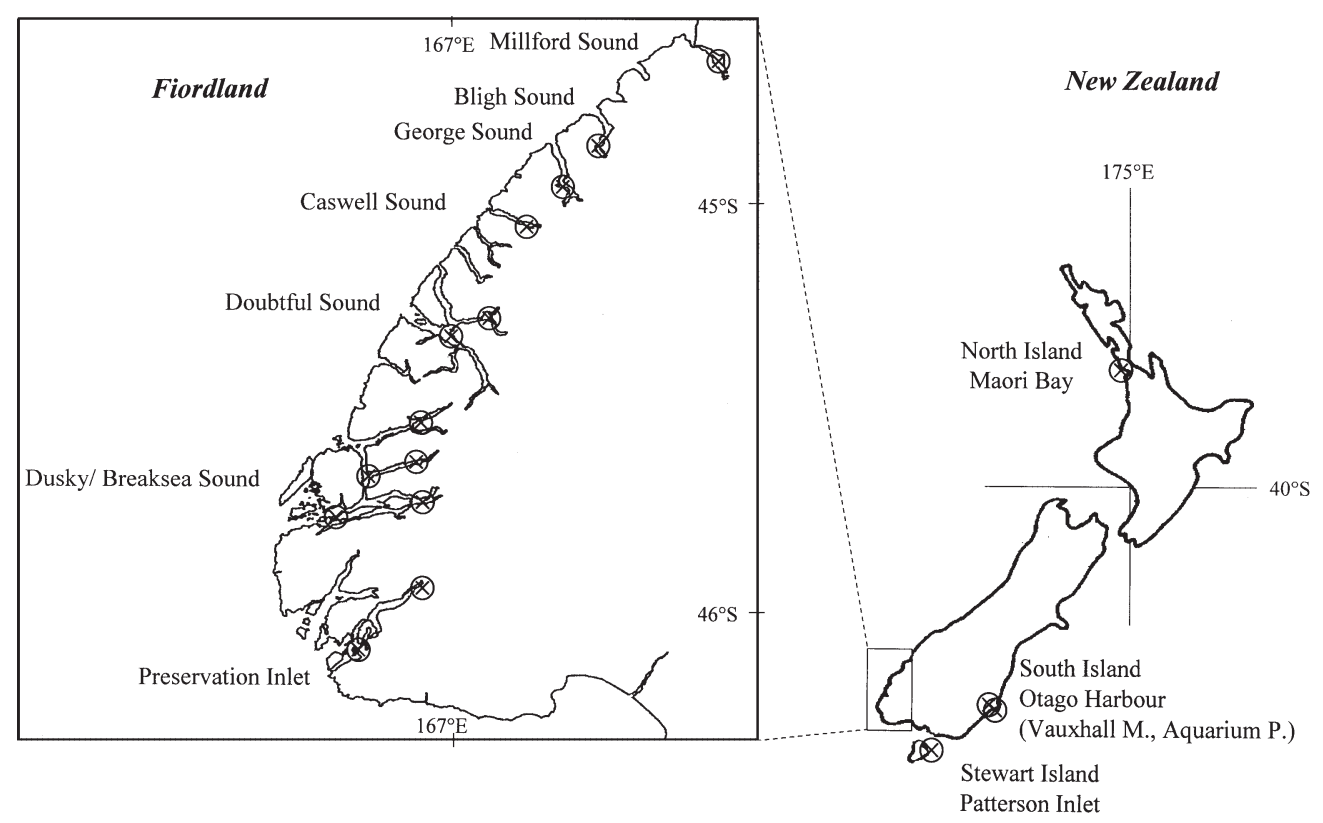

Fig. 1. Locations of sampling sites of Coscinasterias muricata on North Island, South Island, and Stewart Island, New Zealand 


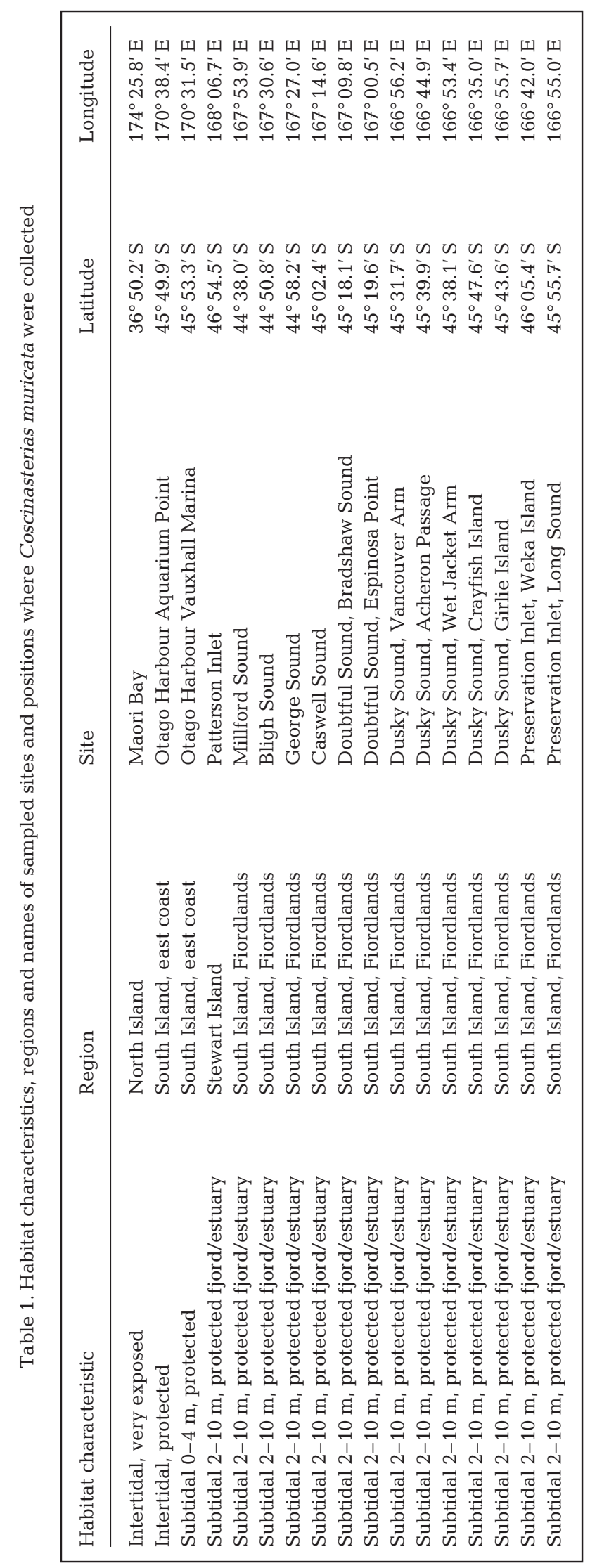

ties of the New Zealand fjords (Witman \& Grange 1998). Spawning is seasonal and occurs between November and March (Crump \& Barker 1985). C. muricata has a free-swimming planktotrophic larva and the length of its pelagic life has been inferred from laboratory culture to be about 30 d (Barker 1978). Sexual recruitment is irregular. In addition to sexual reproduction C. muricata reproduces asexually through fission (Crump \& Barker 1985, Johnson \& Threlfall 1987).

In this study we (1) compare the relative proportion of asexual and sexual reproduction in different habitats with emphasis on the fjords of New Zealand's west coast, using genetics and morphological data; and (2) investigate experimentally the effects of food supply and fluctuating temperature on growth, energy storage in the pyloric caeca, gonad development and fission in a fissiparous population of Coscinasterias muricata.

\section{MATERIAL AND METHODS}

Sample collection. We sampled Coscinasterias muricata in all fjords on the South Island of New Zealand during a 2 wk expedition. Sites were selected where the seastars were abundant. Samples were also collected from Maori Bay on the northwest coast of the North Island, Otago Harbour on the east coast of the South Island, and Stewart Island (Table 1). Samples of 27 to 100 individuals were obtained from 17 sites (Fig. 1) from January to September 1998. Collections were made once for each sample site. Those from the fjords and Stewart Island were sampled from a variety of bottom types from rocks to coarse sediment and from depths of 2 to $10 \mathrm{~m}$, and those from Otago Harbour-Vauxhall Marina and North Island-Maori Bay were sampled among rocks, boulders and pools in the lower intertidal. The population from Otago HarbourAquarium Point was sampled in the shallow subtidal ( 0 to $4 \mathrm{~m}$ ) on sand or among rocks or algae. All seastars were maintained in laboratory tanks until dissection. For genetic analysis, tissue samples were taken from the tube feet and pyloric caeca, put in $1.5 \mathrm{ml}$ Eppendorf tubes, and immediately frozen in liquid nitrogen or in $\mathrm{a}-80^{\circ} \mathrm{C}$ freezer pending analysis. On all seastars, the length of the longest arm (R) was measured from the centre of the disk to the tip of the arm and the number of arms and madreporites were counted. Appearance of having split was assessed by asymmetry, i.e. if the disk appeared to have split and several $(>2)$ proximate arms were regenerating. For the populations from Maori Bay and Otago Harbour that showed signs of having split, all arms were measured and the mean coefficient of variation (CV) was estimated for each population as a complementary assessment of fission. 
For comparison, the CV was also estimated for populations from Stewart Island and Doubtful Sound that showed no signs of being asymmetrical as defined above. Sex was determined by eye after gonad biopsy when possible, i.e. when gonads were present and developed. Deviation from expected sex ratios was tested with a chi-square test.

Electrophoresis. Samples of the tube feet and pyloric caeca (between 24 to 47 from each population) were prepared for electrophoresis by grinding the tissue in 1 to 6 drops of homogenising buffer; $0.02 \mathrm{M}$ tris, $0.1 \%(\mathrm{w} / \mathrm{v})$ mercaptoethanol, $0.1 \%(\mathrm{w} / \mathrm{v})$ bromophenolblue, $\mathrm{pH}=7.5$. Samples were then centrifuged for $3 \mathrm{~min}$ (tube feet) or $8 \mathrm{~min}$ (pyloric caeca) at $4500 \mathrm{rpm}$. Wicks of filter paper were then soaked in the supernatants for running on starch gels $(12 \% \mathrm{w} / \mathrm{v})$ using a lithium hydroxide $(\mathrm{LiOH})$, or tris-maleate (TM) buffer (Buffers 2 and 9 respectively of Selander et al. 1971). A preliminary survey of 15 enzyme systems revealed 4 polymorphic enzymes that could be scored efficiently. TM-buffer and tube feet tissue were used to score phosphoglucose isomerase (Pgi, EC 5.3.1.9), phosphoglucomutase (Pgm, EC 5.4.2.2), and malate dehydrogenase (Mdh-2, EC 1.1.1.37). LiOH-buffer and pyloric caeca tissue were used to score hexokinase $(H k, E C$ 2.7.1.1). Two enzymes, malate dehydrogenase (Mdh-1) and superoxide dismutase (Sod) showed monomorphism and were not further analysed. Staining techniques were based on those of Shaw \& Prasad (1970) and Pasteur et al. (1988).

Genetic analyses. Each sample was treated as representative of a closed breeding population, and the overall effect of asexual recruitment was assessed as the ratio of observed multi-locus genotypic diversity, $G_{0}$ (Black \& Johnson 1979) to that expected under conditions of sexual reproduction with free recombination, $G_{\mathrm{e}}$ (Stoddart \& Taylor 1988). Departure from unity of this ratio provides an index of the combined effects of departures from single-locus Hardy-Weinberg equilibria and multi-locus linkage equilibria. The mean and standard deviation of the expected genotypic diversity, $G_{e}$, under Hardy-Weinberg equilibrium for the same allelic composition, was determined by simulation of sampling from a 500-individual population with random mating, using 500 Monte Carlo simulations and the program SIMSD provided by JA Stoddart (Stoddart \& Taylor 1988). The value of $G_{0}$ was tested against expectation with a Student's $t$-test for comparison of a single observation with the mean of a sample (Sokal \& Rohlf 1995).

Departures of genotypic frequencies from HardyWeinberg equilibrium for each locus in each sample are presented as values of $H_{\mathrm{d}}$, with $H_{\mathrm{d}}=\left[H_{0}-H_{\mathrm{e}}\right] / H_{\mathrm{e}}$ where $H_{0}$ is the observed number, and $H_{\mathrm{e}}$ is the expected number of heterozygotes. Statistical signifi- cance of departures was tested using chi-square tests separately for each locus and combined for each site by the exact Hardy-Weinberg test of Haldane (1954) using the program GENEPOP 3.1b (Raymond \& Rousset 1995).

Fission experiment. This compared the ability to split between small individuals from Otago Harbour and Doubtful Sound. Since frequency of fission is thought to be related to size (Crump \& Barker 1985), and most populations in the fjords were composed of large individuals only, we conducted an experiment to evaluate if fission occurs in small individuals from the fjords. We therefore compared small individuals from one fjord population (Doubtful Sound-Espinosa) comprised primarily of large individuals to small individuals from a fissiparous population (Otago HarbourVauxhall Marina). In the experiment, 13 small individuals from each population (longest arm, R $<55 \mathrm{~mm}$ ) collected from under rocks were kept in individual jars ( $\varnothing: 17.5 \mathrm{~cm}$, height: $17 \mathrm{~cm}$ ) with lids from 28 July to 18 November 1998 (113 d). All jars were supplied with incoming seawater $\left(\mathrm{T}=13.5^{\circ} \mathrm{C}\right)$ at a flow rate of 30 to

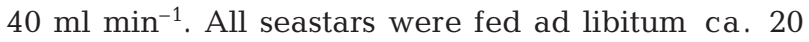
live mussels Xenostrobus pulex (10 to $25 \mathrm{~mm}$ ) individ$\mathrm{ual}^{-1} \mathrm{wk}^{-1}$. Food levels were determined from pilot experiments showing a mean consumption of 14 mussels (X. pulex, 10 to $25 \mathrm{~mm}$ ) $\mathrm{wk}^{-1}$. During the experiment all mussels were removed once a week, and replaced by a new batch. The experiment was checked weekly, and occurrence of fission and initial and terminal individual weights were noted. Parallel to the experiment, 28 small individuals from the same fjord site were kept together in an aquarium at the laboratory, and observed for occurrence of fission over the study period.

Food and temperature experiment. Observations by Barker et al. (1991) suggest that intertidal Coscinasterias muricata divide more frequently than subtidal ones, and proposed factors that may stimulate fission are thermal stress and food availability (Barker et al. 1991). We therefore set up an experiment to evaluate how a daily variation in temperature and food availability influenced growth, gonad development and fission in a 2-factorial design. The experimental system consisted of 24 aquaria units $(33 \times 33 \times 26 \mathrm{~cm})$, containing 2 plastic jars each $(\varnothing: 17.5$, height: $17 \mathrm{~cm})$ with a seastar in each jar. All jars were supplied with incoming sea-

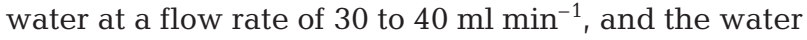
outlet was drained into the aquaria from above to avoid chemical interaction between seastars in the jars. Twelve of the aquaria were heated by a fully immersed heater (Tronic 150W) connected to a digital time switch (Arlec PC787), heating from 09:00 to 15:00 h. The aquaria with the heaters thus acted as water baths and were calibrated to simulate a treatment with a daily 


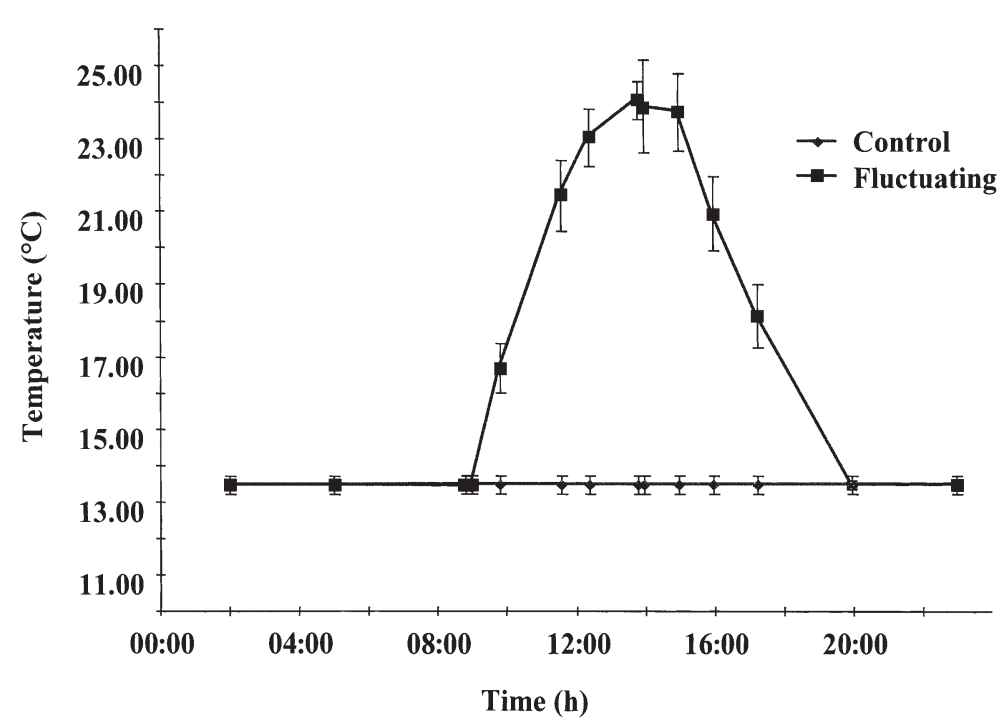

Fig. 2. Fluctuating temperature treatment and the temperature of the controls during daily period of the experiment. Error bars are standard deviation of the mean

temperature fluctuation, increasing from ambient water temperature of ca. $13.5^{\circ} \mathrm{C}$, peaking at $25^{\circ} \mathrm{C}$, and then dropping to ambient incoming water temperature over a total period of approximately $12 \mathrm{~h}$. The fluctuation of the incoming seawater and the temperature treatment are shown in Fig. 2. Food was administered at 3 levels: low ( 2 mussels), intermediate ( 7 mussels), and ad libitum supply (>20 mussels jar ${ }^{-1} \mathrm{wk}^{-1}$ ). As some individuals grew considerably and increased their feeding capacity during the course of the experiment, the ad libitum treatment was increased successively to 35 mussels $\mathrm{wk}^{-1}$. During the experiment all mussels were removed once a week and consumed mussels were counted and replaced by a new batch. All aquaria were placed randomly in a temperature-controlled room $\left(\mathrm{T}=14^{\circ} \mathrm{C}\right)$ with the light on from 06:00 to 18:00 h. On 4 December 1997, the seastars were added. After ascertaining that all individuals were healthy and were feeding, the heaters were turned on and the experiment started the following day. Seastars were collected from a shallow (0 to $4 \mathrm{~m}$ ) subtidal fissiparous population at Otago Harbour-Aquarium Point. The experiment was checked daily and the time that individuals underwent fission was noted. The experiment was terminated on 9 April 1998 after 125 d.

At the start of the experiment all individuals were weighed and videotaped for image-analysis of arm lengths. At the end of the experiment the individuals were again weighed, videotaped, and the wet eviscerated body, pyloric caeca, and gonads were weighed (0.1 mg accuracy). Growth, measured as percentage whole seastar wet wt change during the experiment, was measured regardless of whether an individual had split or not, i.e. when a split resulted in 2 new individuals, these were weighed together. Gonad and pyloric caeca indices were calculated as the weight of tissue expressed as percentage of the eviscerated body weight. Arm lengths were measured with image-analysis using the software NIH Image 1.60. Data were analysed by factorial analysis of variance (ANOVA) with temperature (ambient or fluctuating) and food (low, intermediate or ad libitum) as fixed factors, and aquarium nested in the combinations of temperature and food. Multiple comparisons were made with Student-Newman-Keuls (SNK) tests. Homogeneity of variances was examined using Cochran's C-test ( $<$ 0.05; Snedecor \& Cochran 1989). Organ indices were arcsine-transformed as recommended for proportions (Sokal \& Rohlf 1995).

To determine nutritional state and reproductive condition in the field at the start and termination of the experiment, 10 seastars from the same population were examined in the same way as described above.

\section{RESULTS}

\section{Analysis of clonal structuring of field populations in New Zealand}

\author{
Morphology
}

The populations of Coscinasterias muricata from North Island-Maori Bay, and Otago Harbour-Aquarium Point and Vauxhall Marina frequently showed characteristics of having undergone fission, with a high frequency of individuals with several proximate arms regenerating (all characteristics are summarised in Table 2). Mean numbers of madreporites were 2.4 $(\mathrm{SD}=1.0)$ for Maori Bay, $2.2(\mathrm{SD}=0.9)$ and 1.8 $(\mathrm{SD}=0.7)$ for Otago Harbour. The number of arms (9.7 to $10.2, \mathrm{SD}=1.1$ to 2.1 ) was more variable in the populations from Maori Bay and Otago Harbour than in the fjord populations, where little or no variation in these variables was found (Table 2). Based on asymmetry, i.e. that the disk had split and several arms were regenerating, we calculated that $92 \%$ had undergone fission in the Maori Bay population and 100\% in both populations from Otago Harbour. In contrast we did not observe any characteristics indicating fission in the fjord populations or at Stewart Island. The use of the coefficient of variation $(\mathrm{CV})$ as an indicator of being recently split for the populations from Maori Bay and Otago Harbour showed higher values (0.13 to 0.57 ) 
Table 2. Coscinasterias muricata. Compilation of data on morphology from populations in New Zealand. N: number of individuals examined; R: maximum length of arms; CV: mean coefficient of variation of all arms individual ${ }^{-1}$; nos. in parentheses: standard deviation; -: no visible gonads present; na: not analysed. ${ }^{* * *}$ Significance of deviation of observed versus expected sex-ratio by $\chi^{2}$-test at ${ }^{*} \mathrm{p}<0.05$ and ${ }^{* *} \mathrm{p}<0.001$ respectively

\begin{tabular}{|lccccccccc}
\hline Population & $\mathrm{N}$ & Sex ratio & No. madreporites (SD) & No. arms (SD) & R (SD) & CV \\
\hline North Island, Maori Bay & 38 & $23: 9^{*}$ & 2.4 & $(1.0)$ & 10.2 & $(1.1)$ & 62.6 & $(22.4)$ & 0.23 \\
Otago Harbour, Aquarium Point & 33 & $20: 0^{* *}$ & 2.2 & $(0.9)$ & 10.1 & $(1.1)$ & 52.3 & $(12.3)$ & 0.13 \\
Otago Harbour, Vauxhall Marina & 52 & - & 1.8 & $(0.7)$ & 9.7 & $(2.1)$ & 23.6 & $(9.7)$ & 0.57 \\
Stewart Isl. Patterson Inlet & 41 & $21: 20$ & 1.0 & $(0.2)$ & 10.8 & $(0.6)$ & 141.3 & $(16.5)$ & 0.04 \\
Millford Sound & 49 & na & 1.0 & $(0.0)$ & 10.3 & $(0.3)$ & 121.7 & $(23.2)$ & na \\
Bligh Sound & 32 & na & 1.0 & $(0.0)$ & 10.8 & $(0.5)$ & 189.8 & $(41.7)$ & na \\
George Sound & 48 & na & 1.0 & $(0.0)$ & 10.9 & $(0.4)$ & 149 & $(20.5)$ & na \\
Caswell Sound & 49 & na & 1.0 & $(0.0)$ & 11.0 & $(0.5)$ & 201.4 & $(21.6)$ & na \\
Doubtful Sound, Bradshaw Sound & 45 & $23: 22$ & 1.0 & $(0.0)$ & 10.7 & $(0.6)$ & 187.8 & $(31.4)$ & na \\
Doubtful Sound, Espinosa Point & & & & & & & & \\
$\quad$ Large individuals & 100 & $44: 50$ & 1.0 & $(0.0)$ & 10.7 & $(0.7)$ & 160.2 & $(31.9)$ & 0.12 \\
$\quad$ Small individuals & 36 & - & 1.0 & $(0.0)$ & 10.2 & $(0.9)$ & 33.9 & $(14.8)$ & 0.22 \\
Dusky Sound Vancouver Arm & 50 & na & 1.0 & $(0.0)$ & 10.9 & $(0.3)$ & 176.2 & $(24.1)$ & na \\
Dusky Sound Acheron Passage & 50 & na & 1.0 & $(0.1)$ & 10.8 & $(0.5)$ & 145.2 & $(28.4)$ & na \\
Dusky Sound Wet Jacket Arm & 50 & na & 1.0 & $(0.0)$ & 10.9 & $(0.3)$ & 140.9 & $(22.8)$ & na \\
Dusky Sound Crayfish Island & 27 & na & 1.0 & $(0.0)$ & 10.9 & $(0.3)$ & 167.6 & $(27.2)$ & na \\
Dusky Sound Girlie Island & 50 & na & 1.0 & $(0.0)$ & 11.0 & $(0.4)$ & 126.1 & $(23.5)$ & na \\
Preservation Inlet, Weka Island & 50 & na & 1.0 & $(0.1)$ & 10.7 & $(0.9)$ & 127.3 & $(19.2)$ & na \\
Preservation Inlet, Long Sound & 47 & na & 1.0 & $(0.0)$ & 10.9 & $(0.4)$ & 119.4 & $(21.9)$ & na \\
\hline
\end{tabular}

than for large individuals from Stewart Island and Doubtful Sound-Espinosa Point (0.04 to 0.12). The small individuals from Doubtful Sound-Espinosa Point showed relatively high $\mathrm{CV}$ due to a high occurrence of regenerating arms. However, the arms regenerating in small individuals from Doubtful Sound-Espinosa Point were not proximate, i.e. the individuals showed no signs of having split. Mean sizes based on the longest arm (R) of the populations in the fjords were in general unimodal within sites but differed significantly between sites (1-way ANOVA; $F_{16,796}=178.3, \mathrm{p}=0.0001$ ). Smaller specimens were rarely found in the fjords and, when present, they were usually cryptic under rocks and boulders. For seastars from the few sites in the fjords where low numbers (1 to 10) of small individuals occurred, we never observed any that had split. In the population sampled at Maori Bay a wider range of sizes was found. In Otago Harbour all specimens were small compared to the other populations. Sex-ratio was investigated in 4 populations. The sex-ratio of the Maori Bay population was significantly biased towards males (23:9). The population of Otago Harbour-Aquarium Point was comprised only of males. The small individuals from Otago Harbour-Vauxhall Marina and Doubtful Sound had no visible gonads. The populations from Doubtful Sound (Bradshaw and Espinosa) and Stewart Island had even sex ratios (Table 2).

\section{Genetics}

For the populations of Coscinasterias muricata from Maori Bay and Otago Harbour, values of $G_{0}$ were low and differed significantly from expected values, $G_{\mathrm{e}}$ (Table 3). The lowest ratio of observed versus expected genotypic diversity (0.45) was found for the population in Otago Harbour-Aquarium Point, where only 5 unique genotypes were found among 33 individuals sampled. Strong deviations from Hardy-Weinberg expectations were found at 2 loci ( $H k$ and $M d h-2)$ for seastars from Maori Bay, and at 3 loci for the Otago Harbour populations. Significant deviations with heterozygote deficiency were also found at 1 locus respectively for 5 of the 13 fjord populations $(p<0.05$; $\chi^{2}$-test: Table 3). The exact test of Haldane (1954) over all loci showed extreme deviation from Hardy-Weinberg equilibrium for the populations from Maori Bay and Otago Harbour, but also deviation for 3 populations from the fjords: Millford Sound, Doubtful SoundEspinosa, and Dusky Sound-Acheron (Table 3).

\section{Fission experiment}

The results of the fission experiment are shown in Table 4. All 12 individuals from the fjord population of 
Table 3. Coscinasterias muricata. Compilation of 4 locus measures of genotypic diversity, and analysis of single- and multiple locus Hardy-Weinberg equilibria for populations in New Zealand. $G_{0}$ : observed diversity; $G_{\mathrm{e}}$ : expected diversity; N: number of individuals; $H_{\mathrm{d}}$ : deviation from expected proportion of heterozygotes. $\chi^{2} H_{\mathrm{d}}$ values are for probability multiple-locus test according to Haldane (1954). ${ }^{* * *} G_{0}$ : significant deviation of $G_{0}$ from $G_{\mathrm{e}}$ by Student's $t$-test at $\mathrm{p}<0.001 ;{ }^{* * * * * * *}$ : Significance of deviation for $H_{\mathrm{d}}$ by $\chi^{2}$-test at ${ }^{*} \mathrm{p}<0.05,{ }^{* *} \mathrm{p}<0.01,{ }^{* * *} \mathrm{p}<0.001$

\begin{tabular}{|c|c|c|c|c|c|c|c|c|c|}
\hline Population & $G_{0}$ & $G_{\mathrm{e}}(\mathrm{SD})$ & $G_{0}: G_{\mathrm{e}}$ & $\mathrm{N}$ & $H_{\mathrm{d}}$ Pgi & $H_{\mathrm{d}} \mathrm{Pgm}$ & $H_{\mathrm{d}} H_{\mathrm{k}}$ & $H_{\mathrm{d}} \mathrm{Mdh}$ & $\begin{array}{l}\chi^{2} H_{\mathrm{d}} \\
\text { all loci }\end{array}$ \\
\hline North Island Maori Bay & $16.79^{* * *}$ & $26.64(2.70)$ & 0.63 & 38 & 0.109 & 0.100 & $0.045^{*}$ & $-0.909^{\mathrm{c}}$ & $40.5^{* * *}$ \\
\hline Otago Habour Aquarium Point & $3.07^{* * *}$ & $6.88(0.81)$ & 0.45 & 33 & $-1.000^{* *}$ & 0.000 & $-0.339^{*}$ & $0.900^{\mathrm{c}}$ & $66.1^{* * *}$ \\
\hline Otago Habour Vauxhall Marina & $10.95^{* * *}$ & $17.96(2.21)$ & 0.61 & 37 & $-0.388^{* *}$ & $0.553^{\mathrm{c}}$ & $-0.247^{*}$ & 0.000 & $48.8^{* * *}$ \\
\hline Stewart Isl. Patterson Inlet & 18.96 & $14.69(2.08)$ & 1.29 & 32 & -0.202 & 0.056 & -0.090 & 0.172 & 7.1 \\
\hline Millford Sound & 23.25 & $21.52(2.40)$ & 1.08 & 47 & 0.046 & -0.116 & $-0.473^{*}$ & -0.083 & $17.4^{*}$ \\
\hline Bligh Sound & 15.25 & $15.95(1.91)$ & 0.96 & 31 & 0.239 & -0.156 & -0.157 & -0.109 & 9.2 \\
\hline George Sound & 21.73 & $18.73(2.25)$ & 1.16 & 37 & 0.012 & -0.239 & $-0.352^{*}$ & 0.052 & 13.5 \\
\hline Caswell Sound & 27.77 & $22.61(2.29)$ & 1.23 & 38 & 0.019 & -0.078 & -0.080 & 0.145 & 3.3 \\
\hline Doubtful Sound, Bradshaw Sound & 21.41 & $18.61(1.99)$ & 1.15 & 34 & -0.023 & 0.197 & -0.109 & -0.173 & 4.6 \\
\hline \multicolumn{10}{|c|}{ Doubtful Sound, Espinosa Point } \\
\hline Large individuals & 19.51 & $19.99(2.23)$ & 0.98 & 38 & $-0.095^{* *}$ & -0.084 & -0.168 & -0.210 & $18.9^{*}$ \\
\hline Small individuals & 21.6 & $19.15(2.24)$ & 1.13 & 36 & 0.015 & 0.182 & -0.335 & 0.083 & 8.2 \\
\hline Dusky Sound Vancouver Arm & 14.75 & $14.26(1.99)$ & 1.03 & 29 & 0.022 & 0.096 & -0.233 & 0.013 & 9 \\
\hline Dusky Sound Acheron Passage & 19.29 & $17.72(2.12)$ & 1.09 & 45 & -0.026 & 0.048 & $-0.351^{* *}$ & -0.375 & $17.1^{*}$ \\
\hline Dusky Sound Wet Jacket Arm & 17.48 & $18.07(2.27)$ & 0.97 & 39 & -0.101 & -0.081 & -0.225 & 0.036 & 13.3 \\
\hline Dusky Sound Crayfish Island & 12.52 & $12.73(1.74)$ & 0.98 & 24 & 0.103 & -0.155 & -0.073 & 0.021 & 3.5 \\
\hline Dusky Sound Girlie Island & 18.75 & $18.02(2.10)$ & 1.04 & 30 & 0.173 & 0.130 & $-0.421^{* *}$ & -0.100 & 13.6 \\
\hline Preservation Inlet, Weka Island & 9.44 & $11.40(1.25)$ & 0.83 & 37 & 0.158 & 0.000 & -0.100 & - & 3.4 \\
\hline Preservation Inlet, Long Sound & 16.33 & $14.86(1.85)$ & 1.10 & 40 & -0.049 & 0.053 & -0.219 & 0.025 & 9.2 \\
\hline
\end{tabular}

Doubtful Sound-Espinosa were recovered at the termination of the experiment. None of them had split, and they had increased in size to up to 4.5 times their initial weight. Of the 13 individuals from the population of Otago Harbour-Vauxhall Marina, 4 were recovered at the termination of the experiment. All 4 had split once during the experiment, but the capacity of fission in this population should be interpreted with caution as only 4 individuals were recovered. Mean weight increase was $5 \%$ (Table 4 ).

None of the 28 small individuals from the fjord population kept together in a separate aquarium had undergone fission during the $113 \mathrm{~d}$ period.

In summary, the experiment showed that small individuals from the fjord did not split under conditions

Table 4. Coscinasterias muricata. Fission experiment comparing ability to split between small individuals from Otago Harbour and Doubtful Sound. Numbers in parentheses: standard deviation

\begin{tabular}{|c|c|c|c|c|c|}
\hline Population & $\begin{array}{c}\mathrm{N} \\
\text { (recovered } \\
\text { individuals) }\end{array}$ & Fission & $\begin{array}{c}\text { Initial } \\
\text { weight } \\
\text { (g) }\end{array}$ & $\begin{array}{c}\text { Final } \\
\text { weight } \\
\text { (g) }\end{array}$ & $\begin{array}{c}\text { Weight } \\
\text { increase } \\
(\%)\end{array}$ \\
\hline Otago Harbour & 4 & 4 & $2.82 \quad(1.32)$ & 2.97 & 5 \\
\hline Doubtful Sound & 12 & 0 & $4.70 \quad(2.44)$ & 18.35 (6.21) & 290 \\
\hline
\end{tabular}

that favoured fission for the population from Otago Harbour. Also, the fjord population had a much faster growth rate than the population from Otago Harbour under similar conditions and fed ad libitum.

\section{Food and temperature experiment}

Fission occurred in 15 of the 48 seastars in the experiment, and in all treatments except the low food supply/constant temperature regime. Two seastars split within the first $10 \mathrm{~d}$ of the experiment in the low food supply/fluctuating treatment, while fission also occurred later in the other treatments (Table 5). No mortality occurred during the experiment, and all seastars appeared to behave normally, with the exception of 1 individual that ceased feeding in the second week of the experiment. This individual was not included in the analyses. In 3 individuals that split, 1 single arm was later autotomised. These arms ceased to move after about $2 \mathrm{~d}$ and were removed from the aquaria. Spawning was observed 13 times during the course of the experiment, and in 12 of 
Table 5. Coscinasterias muricata. Food and temperature experiment showing number of seatstars split, days to fission, and initial and final weight. Experimental data: $\mathrm{N}=8$; numbers in parentheses: standard deviation

\begin{tabular}{|c|c|c|c|c|c|c|c|c|}
\hline \multirow{2}{*}{$\begin{array}{l}\text { Food supply } \\
\text { Low }\end{array}$} & \multirow{2}{*}{$\begin{array}{l}\text { Temperature } \\
\text { regime }\end{array}$} & \multirow{2}{*}{$\begin{array}{c}\text { Fission } \\
0\end{array}$} & \multirow[t]{2}{*}{$\begin{array}{l}\text { Days to } \\
\text { fission }\end{array}$} & \multicolumn{2}{|c|}{$\begin{array}{l}\text { Initial weight } \\
\text { (g) }\end{array}$} & \multicolumn{2}{|c|}{$\begin{array}{l}\text { Final weight } \\
\text { (g) }\end{array}$} & \multirow{2}{*}{$\begin{array}{c}\begin{array}{c}\text { Weight change } \\
(\%)\end{array} \\
-10\end{array}$} \\
\hline & & & & 29.37 & $(9.14)$ & 25.92 & $(6.31)$ & \\
\hline Low & Fluctuating & 2 & 7,9 & 37.10 & $(7.67)$ & 28.88 & (5.29) & -21 \\
\hline Intermediate & Control & 4 & $16,28,30,55$ & 33.44 & (8.16) & 40.34 & $(7.12)$ & 24 \\
\hline Intermediate & Fluctuating & 3 & $2,8,56$ & 33.29 & $(6.22)$ & 40.22 & $(7.16)$ & 24 \\
\hline Ad libitum & Control & 3 & $5,75,85$ & 32.29 & $(6.75)$ & 57.32 & (20.78) & 77 \\
\hline Ad libitum & Fluctuating & 3 & $7,23,45$ & 32.03 & $(6.20)$ & 59.86 & (15.95) & 91 \\
\hline
\end{tabular}

these spawning occurred in the fluctuating temperature treatments.

The nested ANOVA revealed effects due to the food treatment $\left(F_{2,18}=36.83, \mathrm{p}=0.0001\right)$, and all treatment terms, i.e. low, intermediate and ad libitum food supply, were different (SNK-test, $\mathrm{p}<0.05$; Fig. 3A), with growth increases paralleling increasing food supply. The highest growth rates were found in the ad libitum
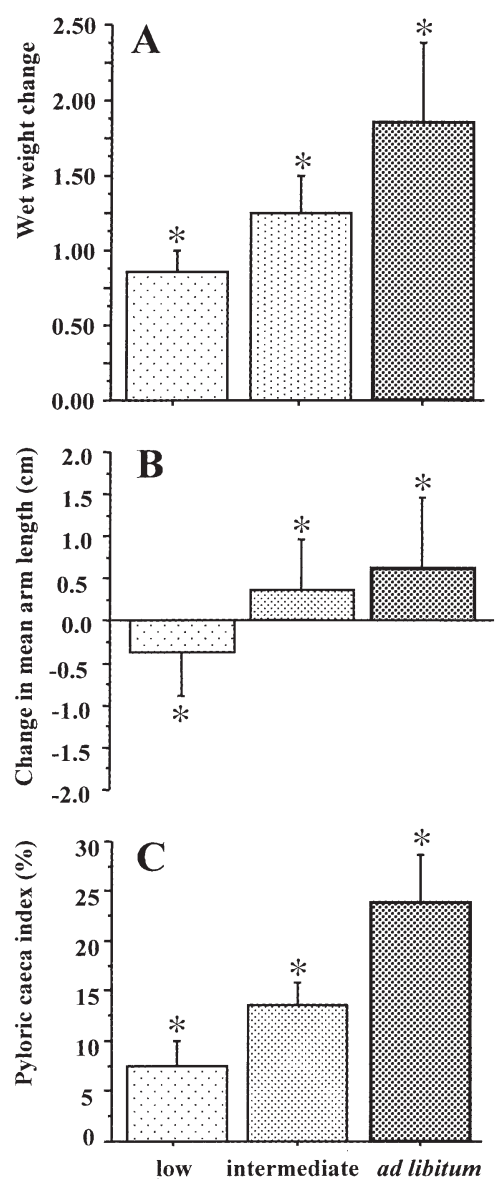

Fig. 3. Coscinasterias muricata. (A) Changes in whole animal wet weight; (B) changes in mean arm length; and (C) pyloric caeca index at the termination of the experiment. $*$ :Significant difference between treatments (SNK-test, $\mathrm{p}<0.05$ ) treatment, where 6 individuals more than doubled their weight over the $125 \mathrm{~d}$ the experiment lasted. None of these 6 individuals underwent fission during the experiment. No effects were found due to the fluctuating temperature treatment. The same pattern was found using change in mean arm length of each individual as dependent variable $\left(F_{2,18}=12.46, \mathrm{p}=0.0004\right.$, Fig. 3B). In the low food supply treatment the seastars starved, as shown by the negative change in mean arm length and loss in weight (Table 5, Fig. 3B).

Similar to the growth variables, effects on the pyloric caeca index were found due to the food treatment $\left(F_{2,18}=108.29, \mathrm{p}=0.0001\right)$. All treatment terms were different (SNK-test, $\mathrm{p}<0.05$; Fig. 3C), with a higher index due to increasing food supply. Gonads were found only in the ad libitum and the intermediate food supply treatments, and were generally small. A significant interaction between food supply and temperature was detected $\left(F_{2,18}=4.68, \mathrm{p}=0.023\right)$, which showed comparatively lower gonad indices in the fluctuating temperature. The interaction is explained by the fact that no gonads were detected in the intermediate food supply-fluctuating temperature regime. The lower gonad indices in the fluctuating temperature treatments thus correlated with the observed spawning by 12 individuals in this treatment.

The organ indices of individuals from the same population in the field showed large gonads in spring, and an inverse relation with pyloric caeca, i.e. a comparatively higher pyloric caeca index in the autumn when the gonad index was low. Comparison of the pyloric caeca index of individuals from the field with experimental individuals at the termination of the experiment showed a good correlation with the intermediate food supply treatment, $13.8 \%$ in the field compared to $13.7 \%$ in the experiment (Table 6).

The weekly feeding observations showed that when supplied with 2 or 7 mussels, the seastars in general consumed all of these. In the ad libitum supply, consumption increased during the course of the experiment and the highest weekly consumption recorded was 35 mussels. The mean number of mussels consumed per week when supplied ad libitum was 13.4 
$(\mathrm{SD}=6.1)$. No effect on feeding capacity (measured as mean mussels consumed per week) due to the fluctuating temperature treatment could be detected $\left(F_{1,42}=\right.$ $0.41, \mathrm{p}>0.05)$.

Regeneration of arms following fission varied from 0 to 7 arms regenerated, and varied considerably within and between individuals. Regeneration rates varied between 0.02 and $0.10 \mathrm{~mm} \mathrm{~d}^{-1}$.

\section{DISCUSSION}

Although fission occurs in several populations of Coscinasterias muricata examined in this study, we found no evidence that fission occurs in the fjords or at Stewart Island. In contrast, and as expected based on earlier studies (Crump \& Barker 1985, Barker et al. 1991), there was morphological evidence of fission, and clonal structuring was inferred from genetics in populations from Maori Bay and Otago Harbour. Geographic and between-habitat variation in the relative proportion of asexual and sexual reproduction in echinoderms has been documented before (see reviews by Emson \& Wilkie 1980 and Mladenov \& Burke 1994). This study is the first to suggest a complete absence of asexual reproduction in a whole region (the New Zealand fjords) with similar habitat characteristics within the normal range of a widely distributed fissiparous species.

\section{Spatial variability in sexual and asexual reproduction in Coscinasterias muricata}

In fissiparous species of seastars the body is usually distinctly asymmetrical, with a set of large and a set of small arms that usually totals more than 5 arms and typically has more than 1 madreporite (Emson \& Wilkie 1980). Morphometrics have also been used in several studies to assess the importance of fission. For several

Table 6. Coscinasterias muricata. Organ indices from the experiment and the field. Experimental data: $N=16$; field data: $\mathrm{N}=10$; numbers in parentheses: standard deviation

\begin{tabular}{|c|c|c|c|c|}
\hline Food supply & \multicolumn{2}{|c|}{ Expt start } & \multicolumn{2}{|c|}{ Expt end } \\
\hline \multicolumn{5}{|l|}{ Pyloric caeca index } \\
\hline Low & - & & 7.3 & $(2.4)$ \\
\hline Intermediate & - & & 13.7 & (2.3) \\
\hline Ad libitum & - & & 23.8 & $(4.5)$ \\
\hline Field & 9.4 & $(2.6)$ & 13.8 & $(4.2)$ \\
\hline Gonad index Low & & & 0.0 & $(0.0)$ \\
\hline Intermediate & - & & 0.2 & $(0.2)$ \\
\hline Ad libitum & - & & 1.1 & $(1.2)$ \\
\hline Field & 4.1 & $(3.7)$ & 0.7 & $(0.8)$ \\
\hline
\end{tabular}

species, including the genus Coscinasterias, there is a coupling between size and occurrence of fission (e.g. Hyman 1955, Crump \& Barker 1985, Johnson \& Threlfall 1987). However, Ottesen \& Lucas (1982) found no such relationship in Nepanthia belcheri. If asexual reproduction through fission decreases with increasing size in C. muricata, the characteristics of fission, i.e. asymmetrical shape, variable number of arms and multiple madreporites, could eventually be lost in populations composed mostly of large individuals. Consequently, there is a need for other tools such as genetic analysis to evaluate if fission occurs in such populations. The sizes of $C$. muricata we found in the New Zealand fjords were considerably larger (>double arm length) than individuals from the other populations at Maori Bay and Otago Harbour, and those investigated by Crump \& Barker (1985) and Barker et al. (1991) in Otago Harbour and by Johnson \& Threlfall (1987) on the coast of Western Australia. The fjord individuals lacked, with very few exceptions, multiple madreporites, had either 10 or 11 arms, and showed no signs of having split. These characters were the strongest morphological indicators of fissiparity. The coefficient of variation was less conclusive, as variability in arm length may vary considerably if single, non-proximate arms are regenerating following autotomy or breakage.

One explanation of the lack of morphological signs of fissiparity for the fjord populations would be that they have reached a critical size at which fission has ceased. However, a historical record of fissiparity should have shown up in the genetic analysis, but no significant deviation of observed $\left(G_{0}\right)$ versus expected $\left(G_{\mathrm{e}}\right)$ genotypic diversity could be detected in the analysis of the 13 fjord populations. In contrast, such deviations were clear for the fissiparous populations from Maori Bay and Otago Harbour.

Since a genetically variable population with high levels of asexual recruitment should display a low ratio of observed versus expected genotypic diversity, the most likely explanation for this deviation from expected genotypic diversity is that the populations from Maori Bay and Otago Harbour are clonally structured and that several members of some of the clones were collected. Assuming that individuals from the populations in the fjords were comparatively old and comprised several well-mixed clones, it is possible that the 4 loci analyses of the populations lacked the power to resolve weak clonal patterns. Of the 14 fjord populations, 5 deviated from Hardy-Weinberg equilibrium, with heterozygote deficiency at 1 locus each.

Possible alternative explanations for heterozygote deficiency are the Wahlund effect (i.e. mixing of zygotes from populations with differing allele frequencies) or inbreeding. Inbreeding is likely, since there is 
genetic differentiation between fjords, possibly due to retention of larvae within fjords (M.S., S. Wing \& P.V.M. unpubl. data). However, the lack of power to identify clones seems unlikely, since the pattern of no deviation of observed $\left(G_{0}\right)$ versus expected genotypic diversity $\left(G_{\mathrm{e}}\right)$ was consequent throughout the fjords. In addition, the small individuals sampled in one of the fjords (Doubtful Sound) showed no signs of fission, did not split in the laboratory under experimental conditions at which individuals within the same size range from Otago Harbour divided, and had no deviation in genotypic diversity from that expected under sexual outcrossing.

Our conclusion is that the phenotype dominant in the New Zealand fjords, and possibly at Stewart Island, is not fissiparous, or that fission is of very little importance in the recruitment of Coscinasterias muricata in these populations. In sharp contrast to these observations is the population from Otago Harbour-Aquarium Point that was surveyed in 1966 to 1969, in 1983 (Crump \& Barker 1985), and regularly since that time (M. F. Barker pers. comm.). The population in all these studies consisted almost entirely of males. We found only 5 unique genotypes among the 33 males sampled, indicating that sexual contribution to the gene pool is very low. It is possible that this population has been maintained mainly by asexual recruitment for at least the last $33 \mathrm{yr}$.

Emson (1978), Crump \& Barker (1985) and Johnson \& Threlfall (1987) found that subtidal populations of Allostichaster polyplax and Coscinasterias muricata generally have a lower incidence of fission, larger body size and larger gonads than intertidal populations. However, they also found individuals showing signs of fission in all subtidal populations. In contrast, we found no signs of fission at all in the fjord populations. One main feature that distinguishes these populations is that those in the fjords are probably strictly subtidal due to the influence of the low-salinity layer (LSL) in the fjords. The hydrography of the fjords is strongly influenced by the phenomenal rainfall (up to $7 \mathrm{~m} \mathrm{yr}^{-1}$ ) in the area (Stanton \& Pickard 1981). The top layer in the LSL is often freshwater. We never observed C. muricata within this zone but frequently in aggregations directly under the sharp halocline, as also described by Witman \& Grange (1998). Although larvae of C. muricata are theoretically able to settle in the intertidal during periods of little rain, they are likely to perish due to their sensitivity to low-salinity conditions (Stickle \& Diehl 1987). A study of the sea urchin Evechinus chloroticus within Doubtful Sound by Lamare (1998) supports this pattern. Lamare found high larval retention consistent with the estuarine circulation of the fjord, with a lack of larvae in the surface layers of the fjord.

In Otago Harbour, we found that the intertidal population at Vauxhall Marina comprised small individuals, while the shallow subtidal ( 0 to $4 \mathrm{~m}$ ) population at Aquarium Point was generally larger. The occurrence of fission (judged from morphological traits at Aquarium Point) suggests, in accordance with other studies, that individuals from this population divided less frequently than those in the intertidal population. However, the difference in size of Coscinasterias muricata in shallow coastal subtidal and intertidal habitats could also be due to size-dependent migration. Proportionally larger specimens should be found deeper, i.e. in the subtidal, since they will face more difficulties finding shelter from desiccation under rocks, cobbles and in pools during low tide than smaller individuals. $C$. muricata is a mobile predator (Witman \& Grange 1998), and might well exploit different habitats at different times of its life and during a tidal cycle. The size distribution of the intertidal population collected at the North Island-Maori Bay is different in that both large and small individuals occur at this site. However, this site is different from the intertidal site in Otago Harbour, as large rock pools provide refuges for large $C$. muricata at low tide. It is most likely an advantage for small individuals to exploit the intertidal, as it may provide shelter from predators that are less able to exploit this stressful environment (Kneib 1987). In many marine organisms, predation is reduced with increasing size (Sebens 1979). This would allow larger seastars to forage in the subtidal. Consequently, the correlative observations of individuals going through fission less frequently in subtidal habitats may also be an effect of migratory behaviour and of larger individuals generally dividing less frequently. Most observations on fissiparous seastars are made on populations that are sympatric, i.e. the populations are not separated other than being designated intertidal or subtidal. However, this does not explain why strictly subtidal C. muricata in the New Zealand fjords do not undergo fission at all.

Mladenov (1996) proposed a basic model depicting how environmental factors might interact to regulate asexual and sexual reproduction in echinoderms. The model proposes that factors associated with environmental characteristics such as food availability, population density, predation levels, habitat stability and seasonal variation in temperature are perceived externally by individuals in a population and delivered to, and interpreted by, internal effectors which direct the expression of asexual or sexual characters. The model suggests that physiological factors, such as fissioninducing substances regulated by external environmental factors, switch on the asexual phenotype in asexual echinoderms. If Coscinasterias muricata in the fjords never reproduce by fission, it might be that the asexual phenotype is not switched on in this particular environment. No fission occurred in our laboratory 
experiment that subjected small individuals from Doubtful Sound to conditions in which small individuals from Otago Harbour underwent fission. This might suggest that if regulation of the expression of the asexual phenotype takes place, it is determined early, possibly already during the larval or early settling stages in C. muricata.

The fjord environments are characterised as sheltered, with restricted water movements, and are similar to stable conditions usually found in deeper environments (Grange et al. 1981). Our observations indicate that the abundance of Coscinasterias muricata on the exposed west coast of New Zealand declines towards the more exposed entrances of the fjords. The observations that small individuals from the fjords can grow extremely fast and increase their body weight up to 4.5 times in $113 \mathrm{~d}$, and that the subtidal populations in the fjords only reproduce sexually and grow considerably larger than other populations investigated, indicate that the fjord environment is also a resource-rich environment for $C$. muricata. Our results suggest that food availability and exposure are thus important environmental factors in regulating phenotypic expression in C. muricata. This could explain why the asexual phenotype is absent from the well-protected fjords. Anthony \& Svane (1995) showed that substratum instability caused by moving mussels in a current-swept habitat significantly increased pedal laceration (fragmentation and clonal proliferation) in a subtidal population of the sea anemone Metridium senile. Larger forms of $M$. senile, with apparently higher clonal diversity, attached to rock walls in deeper sheltered localities compared with shallow current-swept mussel beds of Mytilus edulis (Anthony \& Svane 1994). These observations parallel our own on C. muricata, and further emphasise habitat instability as an important factor in clonal proliferation of invertebrates.

One complementary explanation for the absence of fissiparous phenotypes of Coscinasterias muricata in the fjords could be natural selection against asexual reproduction by fission in the fjord environment, or that the ability to split was lost due to founder effects and random genetic drift when the fjords were successively colonised according to sill depth following the rise of seawater after the last ice-age (Pickrill et al. 1992). M.S., S. Wing \& P.V.M. (unpubl. data) examined the genetic composition of $C$. muricata in New Zealand and found genetic subdivision between populations from the fjord region and other populations in New Zealand. Suggested explanations are that the estuarine circulatory pattern, which acts to retain larvae within the fjords, isolates the fjord populations from the open coast and each other, and that the fjords were recently colonised. This implies a potential for genetic differentiation of this species in the fjord region.

\section{Role of food supply and fluctuating temperature}

Food is a factor that may be in short supply for benthic organisms, e.g. when foraging time is restricted for species that have to shelter during low tide. Our results suggest that starving Coscinasterias muricata cease to split, while fission is independent of fluctuating temperature and food availability as long as they have access to enough food to grow. M. F. Barker, R. Scheibling \& P.V.M. (unpubl. data) also found that over a 12 mo period the fissiparous seastar Allostichaster insignis divided only in treatments in which food was abundant. This suggests that good nutritional conditions are required before seastars will divide. Fission may therefore occur mainly in populations whose nutrient reserves are sufficient to support regeneration of body parts. This raises some doubts that starvation as a form of stress stimulates fission, as has been suggested by several authors (Emson \& Wilkie 1980, Crump \& Barker 1985, Mladenov 1996). Johnson \& Threlfall (1987) conducted feeding experiments with C. muricata and found no correlation between food supply, growth and incidence of fission over a $6 \mathrm{wk}$ period. One explanation for the different results might be that 6 wk was too short or that laboratory holding conditions affected the health of the seastars, as some individuals died during their study (Johnson \& Threlfall 1987). Our results show clearly that growth, nutrient storage and gonad development (and thus sexual reproduction) depend on the availability of food supply.

Comparison of the experimental results with growth in the field also suggests that the population in Otago Harbour indeed experiences food limitation, since gonad indices and nutritional status, measured as pyloric caeca index, are lower in the field than when they are fed ad libitum in the laboratory. Since fissiparity decreases with increasing size in Coscinasterias muricata (Crump \& Barker 1985), and growth rates and gonad development increase with increasing supply of food, we propose that the occurrence of apparently fewer fissiparous individuals in habitats where food is abundant is correlated to food supply. Rapid growth would allow individuals to more quickly reach the size threshold at which fission begins to be suppressed. Conversely, where food supply or feeding time is limiting growth, the pattern would be a relative increase in abundance of small fissiparous individuals. Accordingly, the frequency of sexually reproducing $C$. muricata should increase under conditions where food is abundant.

Mladenov et al. (1983) investigated the possible initiators of fission in short-term laboratory experiments with the brittle star Ophiocomella ophiactoides. They found no evidence that temperature and salinity stress, 
or hypoxic conditions could induce fission in the laboratory, and concluded that exogenous factors are not important and that fission probably is under some form of internal control. Our long-term (125 d) experiment with a fluctuating temperature regime showed no effect on fission that could be associated with this treatment, and thus supports the conclusion regarding temperature by Mladenov et al. (1983). Artificial fission can be induced by incision of the nerve ring in seastars (Emson \& Wilkie 1980), and also by surgical disruption of the disk in brittlestars (Mladenov et al. 1983), supporting the hypothesis that fission in echinoderms is under some form of internal, probably nervously mediated, control.

\section{Conclusion}

We propose that the occurrence of apparently fewer fissiparous individuals in habitats where food is abundant is correlated to food supply. Rapid growth would allow individuals to more quickly reach the size threshold at which fission begins to be suppressed. Conversely, where food supply or feeding time is limiting growth, the pattern would be a relative increase in abundance of small fissiparous individuals. Sizedependent preferences of habitats such as the intertidal and subtidal need also to be considered when assessing characteristics of populations. The frequency of sexually reproducing Coscinasterias muricata should increase under conditions when food is in abundance, as gonad development also depends on food availability. However, the populations from the fjords in New Zealand do not seem to undergo fission at all. The most likely explanation is that the asexual mode of reproduction of this species is not triggered in the subtidal sheltered fjord environment. Another possibility is that natural selection acts against asexual reproduction by fission in the fjord environment, or that the ability to split was lost due to founder effects and random genetic drift when the fjords were successively colonised following the rise in sea level after the last ice-age.

Acknowledgements. We thank Bob Walker (captain of the MV 'Renown', Department of Conservation), Paul Meredith, Steve Wing, Miles Lamare, Nicole Goebel, Paul Brewin, Jason Vasques, Helén Nilsson, Brendan Gould and Peter Stratford for technical assistance in the field, and the staff and management at Portobello Marine Laboratory for help and providing experimental facilities. We thank Leif Pihl, John Lawrence and 2 anonymous referees for criticism of earlier versions of the manuscript. This study was financed by research grants from the Swedish Institute, the Wennergren Center Foundation for Scientific Research, the Helge-Ax:son Johnson Foundation, the Royal Society of Arts and Sciences in Göteborg and the Royal Society for Physical Geography to M.S., and by University of Otago research grants to P.V.M.

\section{LITERATURE CITED}

Anthony KRN, Svane I (1994) Effects of flow habitat on body size and reproductive patterns in the sea anemone Metridium senile (L.) in the Gullmarsfjord, Sweden. Mar Ecol Prog Ser 113:257-269

Anthony KRN, Svane I (1995) Effects of substratum instability on locomotion and pedal laceration in Metridium senile (Anthozoa: Actinaria). Mar Ecol Prog Ser 124:171-180

Barker MF (1977) Observations on the settlement of the brachiolaria larvae of Stichaster australis (Verril) and Coscinasterias calamaria (Gray) (Echinodermata: Asteroidea) in the laboratory and on the shore. J Exp Mar Biol Ecol 30: 95-108

Barker MF (1978) Descriptions of the larvae of Stichaster australis (Verril) and Coscinasterias calamaria (Gray) (Echinodermata: Asteroidea) from New Zealand, obtained from laboratory culture. Biol Bull 177:32-46

Barker MF, Scheibling R, Mladenov P (1991) Seasonal changes in population structure of the fissiparous asteroids Allostichaster insignis (Farquhar) and Coscinasterias calamaria (Gray). In: Scalera-Liaci L, Canicatti C (eds) Echinoderm research. AA Balkema, Rotterdam, p 191-196

Black R, Johnson MS (1979) Asexual viviparity and population genetics of Actinia tenebrosa. Mar Biol 53:27-31

Bucklin A (1987) Growth and asexual reproduction in the sea anemone Metridium: comparative laboratory studies of three species. J Exp Mar Biol Ecol 110:41-52

Chia FS (1976) Sea anemone reproduction: patterns and adaptive radiations. In: Mackie GO (ed) Coelanterate ecology and behavior. Plenum Press, New York, p 261-270

Crump RG, Barker MF (1985) Sexual and asexual reproduction in geographically separated populations of the fissiparous asteroid Coscinasterias calamaria (Gray). J Exp Mar Biol Ecol 88:109-127

Emson RH (1978) Some aspects of fission in Allostichaster polyplax. In: McLusky DS, Berry AJ (eds) Physiology and behaviour of marine organisms. Pergamon Press, Oxford, p 321-329

Emson RH, Wilkie IC (1980) Fission and autotomy in echinoderms. Oceanogr Mar Biol Annu Rev 18:155-250

Giese AC, Pearse JS (1974) Reproduction of marine invertebrates, Vol 1. Academic Press, New York

Grange KR, Singleton RJ, Richardsson JR, Hill PJ, Main Wd (1981) Shallow rock-wall biological associations of some southern fiords of New Zealand. NZ J Zool 8:209-227

Haldane JBS (1954) An exact test for randomness of mating. J Gen 52:631-635

Hughes RN (1989) A functional biology of clonal animals. Chapman \& Hall, London

Hyman LH (1955) The invertebrates: Echinodermata. Vol IV. The Maple Press Company, New York

Johnson MS, Threlfall TJ (1987) Fissiparity and population genetics of Coscinasterias calamaria. Mar Biol 93:517-525

Judson OP, Normark BB (1996) Ancient asexual scandals. Trends Ecol Evol 11:41-46

Kneib RT (1987) Predation risks and use of intertidal habitats by young fish and shrimp. Ecology 68:379-386

Lamare M (1998) Origin and transport of larvae of the sea urchin Evechinus chloroticus (Echinodermata: Echinoidea) in a New Zealand fiord. Mar Ecol Prog Ser 174:107-121

Lawrence JM, Herrera J (2000) Stress and deviant reproduction in echinoderms. Zool Stud 39:151-171

Mladenov PV (1996) Environmental factors influencing asexual reproductive processes in echinoderms. Oceanol Acta 19:227-235

Mladenov PV, Burke RD (1994) Echinodermata: asexual prop- 
agation. In: Adiyodi KG, Adiyodi RG (eds) Reproductive biology of invertebrates, Vol. VI. Part B. Asexual propagation and reproductive strategies. Oxford \& IBH Publishing, New Delhi, p 339-383

Mladenov PV, Emson RH, Colpit LV, Wilkie IC (1983) Asexual reproduction in the West Indian brittle star Ophiocomella ophiactoides (H.L. Clark) (Echinodermata: Ophiuroidea). J Exp Mar Biol Ecol 72:1-23

Ottesen PO, Lucas JS (1982) Divide or broadcast: interrelation of asexual and sexual reproduction in a population of the fissiparous hermaphroditic seastar Nepanthia belcheri (Asteroidea: Asterinidae). Mar Biol 69:223-233

Pasteur N, Pasteur G, Bonhomme F, Catalan J, Britton-Davidian J (1988) Practical isozyme genetics. Ellis Horwood, Chichester

Pickrill RA, Fenner JM, McGlone MS (1992) Late Quarternary evolution of a fiord environment in Preservation Inlet, New Zealand. Quat Res 38:331-346

Raymond M, Rousset F (1995) GENEPOP (version 1.2): population genetics software for exact tests and ecumenicism. J Hered 86:248-249

Sebens, KP (1979) The energetics of asexual reproduction and colony formation in benthic marine invertebrates. Am Zool 19:683-699

Editorial responsibility: John Lawrence (Contributing Editor), Tampa, Florida, USA
Selander RK, Smith MH, Yang SY, Johnson WE (1971) Biochemical polymorphism and systematics in the genus Peromyscus. I. Variation in the old field mouse Peromyscus polionotus. Stud Genet 6:49-90

Shaw CR, Prasad R (1970) Starch gel electrophoresis of enzymes-a compilation of recipes. Biochem Genet 4: 297-320

Snedecor GW, Cochran WG (1989) Statistical methods. Iowa State University Press, Ames

Sokal RR, Rohlf FJ (1995) Biometry: the principles and practice of statistics in biological research, 3rd edn. WH Freeman \& Co., New York

Stanton BR, Pickard GL (1981) Physical oceanography of the New Zealand fiords. NZ Oceanogr Inst Mem 88:37

Stickle WB, Diehl WJ (1987) Effects of salinity on echinoderms. In: Jangoux M, Lawrence JM (eds) Echinoderm studies. 2. AA Balkema, Rotterdam, p 235-285

Stoddart JA, Taylor J (1988) Genotypic diversity: estimation and prediction of samples. Genetics 118:705-711

Williams GC (1975) Sex and evolution. Princeton University Press, Princeton, NJ

Witman JD, Grange KR (1998) Links between rain, salinity, and predation in a rocky subtidal community. Ecology 79: 2429-2447

Submitted: July 31, 2001; Accepted: January 28, 2002

Proofs received from author(s): April 22, 2002 